\title{
地震時転倒モーメント下における骨組の外柱の座屈耐力 THE BUCKLING STRENGTH OF OUTER COLUMNS UNDER OVERTURNING MOMENTS DUE TO EARTHQUAKES
}

\author{
秋山宏*, 原田幸博**
}

Hiroshi AKIYAMA and Yukihiro HARADA

\begin{abstract}
The method for estimating the ultimate strength of outer columns in multi-story frame under earthquakes is not established yet. It yields an underestimate of the buckling strength of outer column to take the column length for buckling length as is applied expediently, because outer column buckling under earthquakes is considered to be a phenomenon which takes place under the controlled horizontal displacement. The authors investigate experimentally and analytically the relation between horizontal displacement and buckling strength of outer columns in multi-story frame, and, using these results, propose a design formula for outer columns subjected to the over-turning moment under earthquakes.
\end{abstract}

Keywords : overturning moment, column buckling, effective length factor

転倒モーメント, 柱の座屈, 座屈長さ係数

\section{1. 序}

現在、地震動下の多層骨組外柱の終局耐力を的確に 評価する方法は未だ確立されていない。便法として、 階高を座屈長さと仮定して部材耐力を評価することは できるが、柱頭の水平移動が拘束されている場合には、 座屈長さは材長の半分にまで低下し得る。また、水平 地震力による逆対称曲げモーメント下の柱の曲げ耐力 に及ぼす $P-\delta$ 効果の影響も過大に評価されているのが 現状である。

通常の多層骨組構造については、上述のような便法 をとっても座屈耐力評価上の問題は少ない。何故なら、 通常の多層骨組構造では下層部の柱の細長比は50以下 であり、この程度の細長比の柱では座屈耐力はほぼ降 伏軸力に達しているからである。

一方、層のエネルギ吸収能力を增大させようとする と、一つの層に弾性変形量の大きな柔要素と塑性変形 能力に富む風要素を混在させることが有効となる。こ
のような柔剛混合型骨組においては、柱の細長比は必 然的に大きなものが要求される。

本論文は、柱の細長比が50以上で座屈耐力が降伏軸 力を大きく下回る場合について、骨組外柱の座屈耐力 を柱の水平変位との関連において評価することを目的 とする。

地震力は慣性力としてとらえることができる。慣性 力は時々刻々の質点の変位応答に対応し連続的に変化 し、骨組の復元力と釣り合っている。この意味では、 地震荷重は変位制御型の荷重である。したがって、外 柱の座屈問題は制御された水平変位下における座屈耐 力の問題として扱うことができる。

柔㴊混合型骨組の柱について、既にいくつかの研究 結果が報告されている。寺田ら”は骨組に転倒モーメ ントを作用させた場合の柱の座屈長さ係数が 1 より小 さくなることを骨組模型実験により示している。また、 変位制御下の柱の変形と耐力を実験的に求めた三山、
* 東京大学工学部建築学科 教授. 工博

** 東京大学工学部建築学科 大学院生・修士 (工学)
Prof., Dept. of Architecture, Faculty of Engineering, Univ. of Tokyo, Dr. Eng.

Graduate Student, Dept. of Architecture, Faculty of Engineering, Univ. of Tokyo, M. Eng. 
秋山2)の最新の研究がある。本研究もこれらと軌を一 にしたもので、多層骨組外柱の座屈耐力を柱の水平変 位との関係において実験的に定量化し、解析結果と合 わせて設計式を提案している。

実験には、細長い柱を最下層に持つ骨組模型を用い ている。骨組模型の最下層に外柱及びその他の耐震要 素を配置し、骨組の重心位置に相当する上層部の1点 に集中水平力を作用させて、転倒モーメントによる軸 力を外柱に導入する。最下層の耐震要素弾性に留ま る場合と塑性変形する場合からなり、外柱には軸力と 同等に任意の水平変形を与えることができる。水平変 形の進展に伴って外柱は塑性化が進行し、塑性化の進 展に伴って座屈耐力が低下していく。ある変形状態で、 外柱は軸方向の釣合い状態を喪失して座屈耐力に達す る。

\section{2. 模型実験}

\section{1 実験概要}

実験は多層骨組をモデル化した模型により行った。 実験に用いた模型では、多層骨組の第1層を4本の柱と 水平抵抗ばね(以下、立体ラーメンと呼ぶ)に、上層部 分を剛なフレーム(以下、上部フレームと呼ぶ)にモデ ル化している。立体ラーメンの4本の柱の軸力が明確 にわかるように、水平抵抗ばねは軸力を受けないよう にした(図1)。

上部フレームの1点に水平集中荷重を加えることに より、第1層の立体ラーメンに転倒モーメントと水平 力を作用させた。水平荷重を加えるにつれて第1層の 柱の軸力と水平変形は同時に增加していく。そしてあ る軸力・変形状態になると、圧縮の付加軸力を受ける 側の柱が座屈して耐力を失い、ラーメンが崩壊して終 局状態に至る。ここでは、水平抵抗ばるの㴊性・強度 を様々に変化させて実験を行い、柱の座屈で決まる終 局状態での転倒モーメントとラーメンの水平変位との 関倸を調べた。

\section{2 実験装置}

立体ラーメンは上スラブ、下スラブ及び試験体であ る4本の外柱と2本の中柱で構成される。上スラブには 外柱の取付部と中柱に接触するナイフエッジ、下スラ ブには外柱・中柱の取付部がある。外柱には磨き鋼棒 （矩形断面 $b \times d=6 \mathrm{~mm} \times 2 \mathrm{~mm}$ ) を適当な長さに切って 用い、中柱には様々な大きさと厚さの鋼板を用いる。

外柱の柱頭・柱脚部分と中柱の柱脚部分で、上下ス ラブの柱取付部と柱固定治具の間に外柱及び中柱をは さんで高力ボルトで強く締め付けて、それにより生じ る固定治具と試験体との間に生じる摩擦力によって固 定する。つまり、外柱は柱頭・柱脚ともに回転拘束の 意味における固定端、中柱は柱脚のみ固定端、柱頭は 上スラブに取り付けたナイフェッジによるピン支持と
なる。

上部フレームは中央の加力柱と左右に伸びた水平梁 で構成される。水平梁に載せるおもりの個数を変える ことにより、外柱に作用する固定荷重を変化させるこ とができる。おもりは、おもりに空けてある穴にネジ 棒を通してボルトで締め付けることによって、上部フ レームに固定する。水平荷重は反カフレームに固定し たオイルジャッキによって、ナイフエッジを介して上 部フレームの加力柱の最上部に作用させる。

立体ラーメン部分の四隅に1個ずつ、上部フレーム の水平梁に2個、合計6個のダイヤルゲージを設置して、 立体ラーメン部分の水平変位と四隅の鉛直変位を測定 する。

2.3 パラメータ

実験に際しては、以下の三つをパラメータとして 様々に変化させて実験を行った。

1. 外柱の長さ (細長比)

外柱部分の長さは、 $4 \mathrm{~cm}, 6 \mathrm{~cm}, 8 \mathrm{~cm}, 10 \mathrm{~cm}, 12 \mathrm{~cm}$ （細長比入はそれぞれ 69.3，103.9，138.6，173.2， 207. 8)の5通りとした。細長比 $\lambda$ は外柱の自由長 $l$ を外柱の回転半径で除した值である。さらに外柱 の上下端には上スラブ及び下スラブへの取付けの ために各々 $30 \mathrm{~mm}$ の取付けしろが必要である。

2. 中柱の強度・剛性

中柱には鋼種SS400 の板を用い、板厚と幅を変え て強度と剛性を様々に変化させた。用いる鋼板の 板厚は $2 ， 3 ， 4 \mathrm{~mm}$ の3種類とした。

3. 固定荷重

固定荷重は上部フレームの重量と上部フレームの 左右に載せるおもりの重量との和で定まる。上部 フレームの重量は100kgf、おもり1枚の重量は40kgf である。おもりは上部フレーム水平梁の左右両側 に同じ枚数だけ載せるので、左右両側にそれぞれ おもりを $n$ 枚載せる場合、外柱 1 本当たりに作用す る固定荷重の大きさは $(100+40 \times 2 \times n) / 4 \mathrm{kgf}$ とな る。

実験を行った全46試験体について各パラメータのー 覧を表1に示す。

2.4 素材の性質

図2に外柱部分に用いた磨き鋼棒の引張試験で得ら れた応力度一歪関係の例を示す。引張試験は、試験体 を切り出した 20 本の磨き銅棒のそれぞれについて適当 な長さで切り出した1本を素材試験片とした。引張試 験の結果から、20本の磨き鋼棒の素材は全てほぼ同一 のものであると判断できた。降伏応力度 $\sigma_{y}$ は $0.2 \%$ offset 法によって求めた。

図3に中柱部分に用いた鋼板の素材の引張試験で得 られた応力度-歪度関保の結果を示す。引張試験はJIS 規格の5号試験片を用いて行った。 


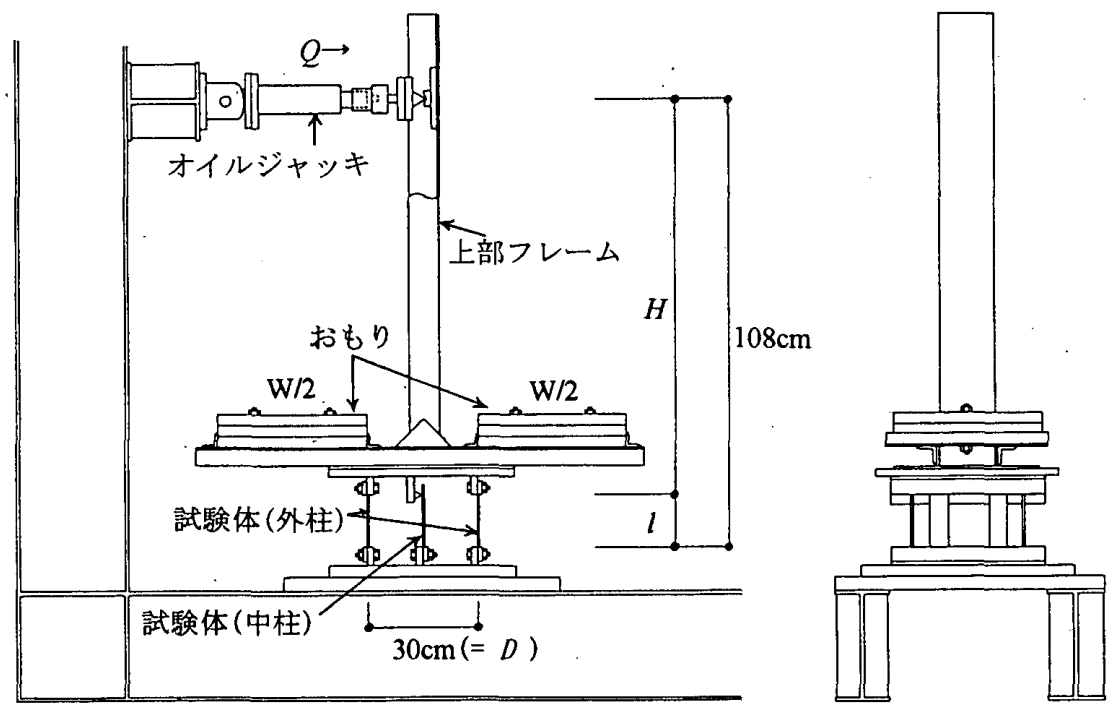

图1 实跧装置

表1 实路パラメータ

\begin{tabular}{|c|c|c|c|c|c|c|}
\hline \multirow{2}{*}{$\begin{array}{c}\text { 試験体 } \\
\text { 名 }\end{array}$} & \multirow{2}{*}{$\begin{array}{c}l \\
(\mathrm{~cm}) \\
\end{array}$} & \multirow{2}{*}{$\begin{array}{c}\text { 細長比 } \\
\lambda\end{array}$} & \multirow{2}{*}{$\begin{array}{c}W \\
(\mathrm{kgf})\end{array}$} & \multirow[t]{2}{*}{ 軸力比 } & \multicolumn{2}{|c|}{ 中柱楼面 } \\
\hline & & & & & $b_{s}(\mathrm{~cm})$ & $d_{s}(\mathrm{~cm})$ \\
\hline $12-01$ & 12 & 207.8 & 100 & 0.044 & 20 & 0.43 \\
\hline $12-02$ & 12 & 207.8 & 100 & 0.044 & 10 & 0.43 \\
\hline $12-03$ & 12 & 207.8 & 100 & 0.044 & 20 & 0.31 \\
\hline $12-04$ & 12 & 207.8 & 100 & 0.044 & 10 & 0.31 \\
\hline $12-05$ & 12 & 207.8 & 100 & 0.044 & 20 & 0.22 \\
\hline $12-06$ & 12 & 207.8 & 180 & 0.078 & 20 & 0.43 \\
\hline $12-07$ & 12 & 207.8 & 180 & 0.078 & 20 & 0.31 \\
\hline $12-08$ & 12 & 207.8 & 180 & 0.078 & 20 & 0.22 \\
\hline $10-01$ & 10 & 173.2 & 100 & 0.044 & 20 & 0.43 \\
\hline $10-02$ & 10 & 173.2 & 100 & 0.044 & 20 & 0.31 \\
\hline $10-03$ & 10 & 173.2 & 100 & 0.044 & 20 & 0.22 \\
\hline $10-04$ & 10 & 173.2 & 260 & 0.113 & 20 & 0.43 \\
\hline $10-05$ & 10 & 173.2 & 260 & 0.113 & 10 & 0.43 \\
\hline $10-06$ & 10 & 173.2 & 260 & 0.113 & 20 & 0.31 \\
\hline $10-07$ & 10 & 173.2 & 260 & 0.1 & 10 & 0.31 \\
\hline $10-08$ & 10 & 173.2 & 260 & 0.113 & 20 & 0.22 \\
\hline $8-01$ & 8 & 138.6 & 100 & & 20 & 0.43 \\
\hline $8-02$ & 8 & 138.6 & 100 & & 20 & 0.31 \\
\hline $8-03$ & 8 & 138.6 & 100 & 0.044 & 20 & 0.22 \\
\hline $8-04$ & 8 & 138.6 & 340 & 0.148 & 20 & 0.43 \\
\hline $8-05$ & 8 & 138.6 & 340 & 0.148 & 10 & 0.43 \\
\hline $8-06$ & 8 & 138.6 & 340 & 0.148 & 20 & 0.31 \\
\hline 8-07 & 8 & 138.6 & 340 & 0.148 & 10 & 0.31 \\
\hline $8-08$ & 8 & 138.6 & 340 & 0.148 & 20 & 0.22 \\
\hline
\end{tabular}

\begin{tabular}{|c|c|c|c|c|c|c|}
\hline 試倹体 & $l$ & 細長比 & $W$ & 軸力比 & \multicolumn{2}{|c|}{ 中柱断面 } \\
\cline { 5 - 7 } 名 & $(\mathrm{cm})$ & $\lambda$ & $(\mathrm{kgf})$ & & $b_{S}(\mathrm{~cm})$ & $d_{s}(\mathrm{~cm})$ \\
\hline $06-01$ & 6 & 103.9 & 100 & 0.044 & 20 & 0.43 \\
$06-02$ & 6 & 103.9 & 100 & 0.044 & 10 & 0.43 \\
$06-03$ & 6 & 103.9 & 100 & 0.044 & 20 & 0.31 \\
$06-04$ & 6 & 103.9 & 100 & 0.044 & 10 & 0.31 \\
$06-05$ & 6 & 103.9 & 100 & 0.044 & 20 & 0.22 \\
$06-06$ & 6 & 103.9 & 340 & 0.148 & 20 & 0.43 \\
$06-07$ & 6 & 103.9 & 340 & 0.148 & 20 & 0.31 \\
$06-08$ & 6 & 103.9 & 340 & 0.148 & 20 & 0.22 \\
$06-09$ & 6 & 103.9 & 580 & 0.253 & 20 & 0.43 \\
$06-10$ & 6 & 103.9 & 580 & 0.253 & 20 & 0.31 \\
$06-11$ & 6 & 103.9 & 580 & 0.253 & 20 & 0.22 \\
\hline $04-01$ & 4 & 69.3 & 100 & 0.044 & 20 & 0.43 \\
$04-02$ & 4 & 69.3 & 100 & 0.044 & 10 & 0.43 \\
$04-03$ & 4 & 69.3 & 100 & 0.044 & 20 & 0.31 \\
$04-04$ & 4 & 69.3 & 100 & 0.044 & 10 & 0.31 \\
$04-05$ & 4 & 69.3 & 100 & 0.044 & 20 & 0.22 \\
$04-06$ & 4 & 69.3 & 500 & 0.218 & 20 & 0.43 \\
$04-07$ & 4 & 69.3 & 500 & 0.218 & 20 & 0.31 \\
$04-08$ & 4 & 69.3 & 500 & 0.218 & 20 & 0.22 \\
$04-09$ & 4 & 69.3 & 900 & 0.392 & 20 & 0.43 \\
$04-10$ & 4 & 69.3 & 900 & 0.392 & 20 & 0.31 \\
$04-11$ & 4 & 69.3 & 900 & 0.392 & 20 & 0.22 \\
\hline
\end{tabular}

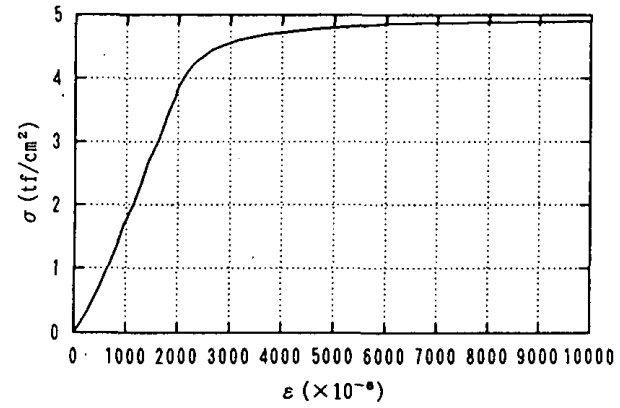

图2 繋材試展結果（外拄）

表2 素材の性贯（外柱）

\begin{tabular}{|c|c|}
\hline $\begin{array}{c}\text { ヤング保数 } \\
\left(\mathrm{tf} / \mathrm{cm}^{2}\right)\end{array}$ & $\begin{array}{c}\text { 降伏忘力度 } \\
\left(\mathrm{tf} / \mathrm{cm}^{2}\right)\end{array}$ \\
\hline 2080.6 & 4.78 \\
\hline
\end{tabular}

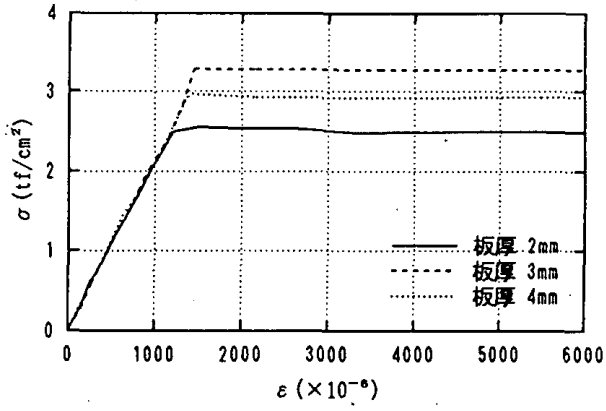

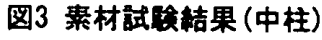

表3 慗材の性篰（中柱）

\begin{tabular}{|c|c|c|}
\hline $\begin{array}{c}\text { 板厚 } \\
(\mathrm{mm})\end{array}$ & $\begin{array}{c}\text { ヤング係数 } \\
\left(\mathrm{t} / \mathrm{cm}^{2}\right)\end{array}$ & $\begin{array}{c}\text { 降伏志力度 } \\
\left(\mathrm{t} / \mathrm{cm}^{2}\right)\end{array}$ \\
\hline 2.3 & 2130.9 & 2.49 \\
\hline 3.3 & 2162.3 & 3.27 \\
\hline 4.1 & 2080.6 & 2.92 \\
\hline
\end{tabular}


表2,3に外柱、中柱の素材の性質を示す。

\section{5 実験結果}

実験から得られた水平荷重とラーメンの水平変位の 関係を図4に示す。ただし図4では、ラーメンの水平変 位 $\delta$ は軸力がない場合の外柱の弾性限界変位 $\delta_{\mathrm{y} 0}$ で除 して無次元化しており、水平荷重はラーメンの圧縮側 の柱に作用している圧縮応力度 $\sigma$ に換算して、それを 降伏応力度 $\sigma_{\mathrm{y}}$ で除して無次元化して示している。ここ で、 $\delta_{y 0}, \sigma$ は次の式で定める。

$$
\begin{aligned}
\delta_{\mathrm{y} 0} & =\frac{b d^{2} l^{2} \sigma_{\mathrm{y}}}{36 E I} \\
& =\frac{\sigma_{\mathrm{y}} l^{2}}{3 E d} \\
\sigma & =\sigma_{0}+\sigma_{\mathrm{ov}} \\
\sigma_{0} & =\frac{W}{4} / A \\
\sigma_{\mathrm{ov}} & =\frac{1}{2} \frac{M_{\mathrm{ov}}}{D} / A \\
& =\frac{1}{2} \frac{Q H}{D} / A
\end{aligned}
$$

ここで、

$b, d, l:$ 外柱の幅, せい, 長さ

$I, A$ ：外柱の断面二次モーメント，断面積

$E:$ 外柱のヤング率

$\sigma_{0}$ ：固定荷重による外柱の圧縮応力度

$\sigma_{\mathrm{ov}}$ ：転倒モーメントにより加わる圧縮応力度

$W:$ ラーメンに作用する全固定荷重

$Q:$ 上部フレームに作用させる水平力

$H$ : 外柱上端から加力点までの高さ $(108-l \mathrm{~cm})$

$\mathrm{M}_{\mathrm{ov}}$ ：ラーメンに作用する転倒モーメント $(Q H)$

$D$ : 外柱の加力方向のスパン $(30 \mathrm{~cm})$

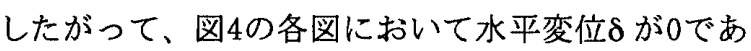
るとき、つまり水平力を加えていないときには、。 $=\sigma_{0}$ であり、 $\delta / \delta_{\mathrm{y} 0}=0$ のときの $\sigma / \sigma_{\mathrm{y}}$ の值は $\sigma_{0} / \sigma_{\mathrm{y}}$ と なり0とはならない。図4では、加力を開始してから ラーメンの柱が座屈しラーメンが崩壊するまでの状態 をプロットしている。

図4によると水平力と水平変位の関係には、

1. 水平力の増加とともに水平変位も増加し座屈する もの

2. 始めは水平力の増加とともに水平変位も増加する が、途中からは水平力がゆるやかに減少しながら 水平変位が増加していって座屈するもの

の二通りがあることがわかる。1. は座屈時まで中柱が 弾性にとどまっていることを示しており、2.は途中か ら中柱の下端部が塑性化しで中柱の水平耐力が上昇し なくなり、外柱は水平変位の増加につれて $P-\delta$ 効果に より水平耐力が減少するため、ラーメン全体の水平耐 カが減少していくことを示している。図中には細実線 で次式による $P-\delta$ 効果の負勾配を示す。

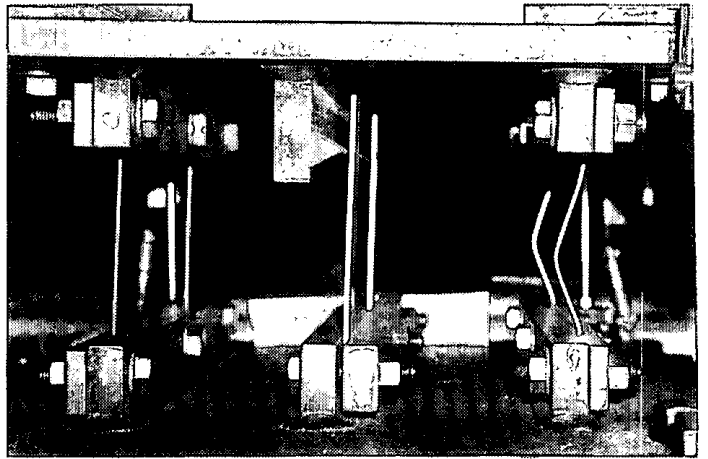

写真1 座届状況 $(l=12 \mathrm{~cm})$

$$
k_{P \delta}=-\frac{W}{l}
$$

したがって、水平力と水平変位の関係は中柱の強度が 大きい場合には1、、小さい場合には2.のようになる。

写真1に立体ラーメン部分の座屈時の状況の一例を 示す。座屈現象は、水平変位の増大に伴って徐々に進 展するものではない。座屈モードは圧縮外柱の軸方向 変形を伴うものであり、水平変位、転倒モーメントが ある状態に達したときに突然に起こり、座屈現象を計 測することは不可能である。左側の引張側の外柱は軸 方向変形をほとんど生じず座屈前の圧縮側の外柱の変 形を示しているとみなせる。本実験の全ての試験体に ついて圧縮側の柱は軸方向変形下において写真1と同 様の、柱頭・柱脚・中央部付近の3ヶ所にヒンジが発 生する座屈モードを示した。このように、外柱の座屈 は水平変位拘束下で生じる現象であるといえる。

各柱長さについて圧縮側柱の座屈時の圧縮応力度 $\sigma_{\mathrm{cr}}$ と座屈時の水平変位 $\delta_{\mathrm{cr}}$ をプロットしたものを図 6に示す。図4と同様の方法で無次元化して示している。 また、図6には細実線で1次、破線で2次の座屈モード に対応する Tangent modulus theory による座屈圧縮応 力度 $\sigma_{\mathrm{cr} 1}\left(=\pi^{2} E_{t} / \lambda^{2}\right), \quad \sigma_{\mathrm{cr} 2}\left(=4 \pi^{2} E_{t} / \lambda^{2}\right)$ の值も示して いる。図6から、次のことがわかる。

1. 柱長さが $4 \mathrm{~cm}$ 試験体を除いて、ほぼ $\sigma_{\mathrm{cr} 1}<\sigma<\sigma_{\mathrm{cr} 2}$

が成り立っている。

2. $\delta_{\mathrm{cr}}$ と $\sigma_{\mathrm{cr}}$ の間には、 $\delta_{\mathrm{cr}}$ が増加するにつれて $\sigma_{\mathrm{cr}}$ が減少していく関係がある。また、その関係は固 定荷重 $W$ にらず、外柱の長さlだけで定まる。

2. から、転倒モーメント下におけるラーメンの柱の 座屈は、固定荷重の大小には依存せず、転倒モーメン ト下での圧縮側の柱の軸力（固定荷重による軸力と転 倒モーメントにより付加される軸力の和)のみで決ま るといえる。 

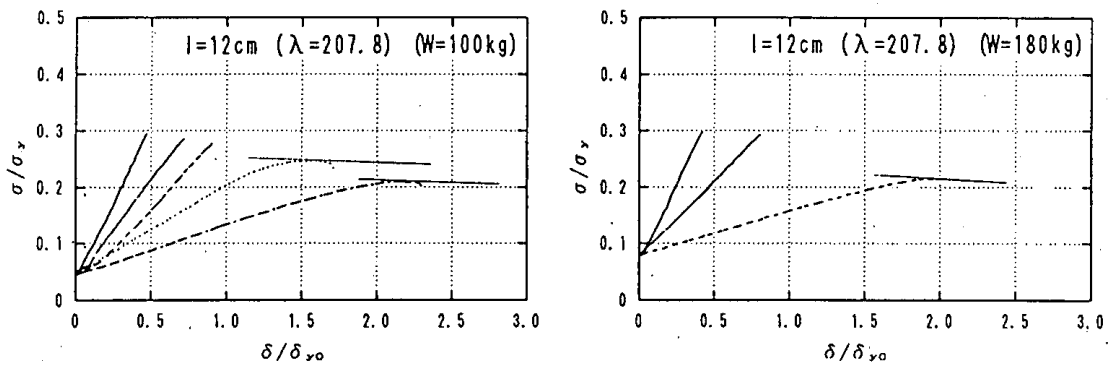

$l=12 \mathrm{~cm}(\lambda=207.8)$
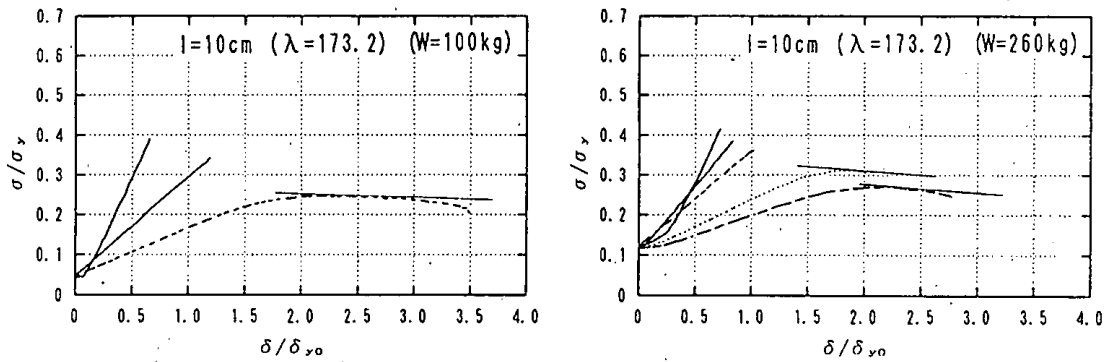

$l=10 \mathrm{~cm}(\lambda=173.2)$
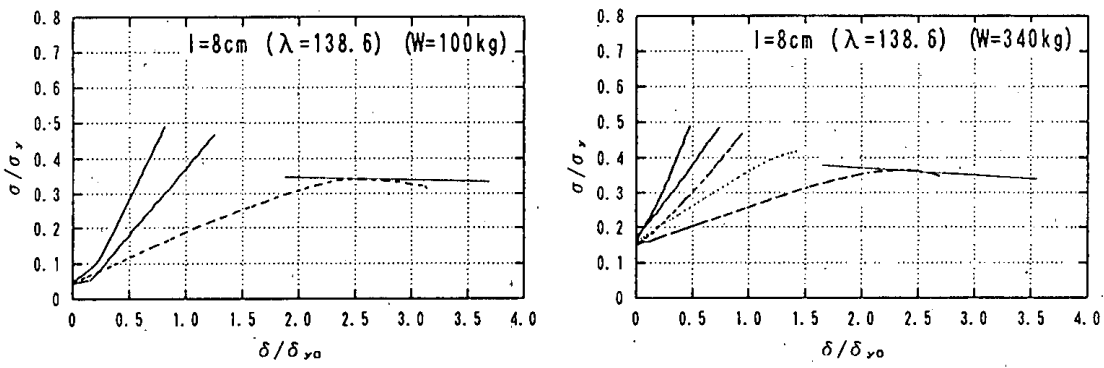

$l=8 \mathrm{~cm}(\lambda=138.6)$
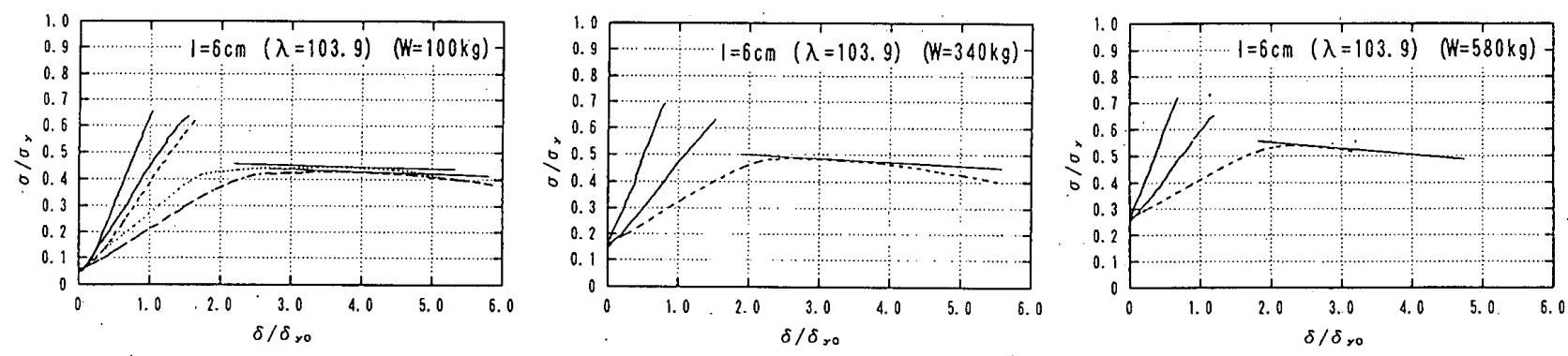

$l=6 \mathrm{~cm}(\lambda=103.9)$
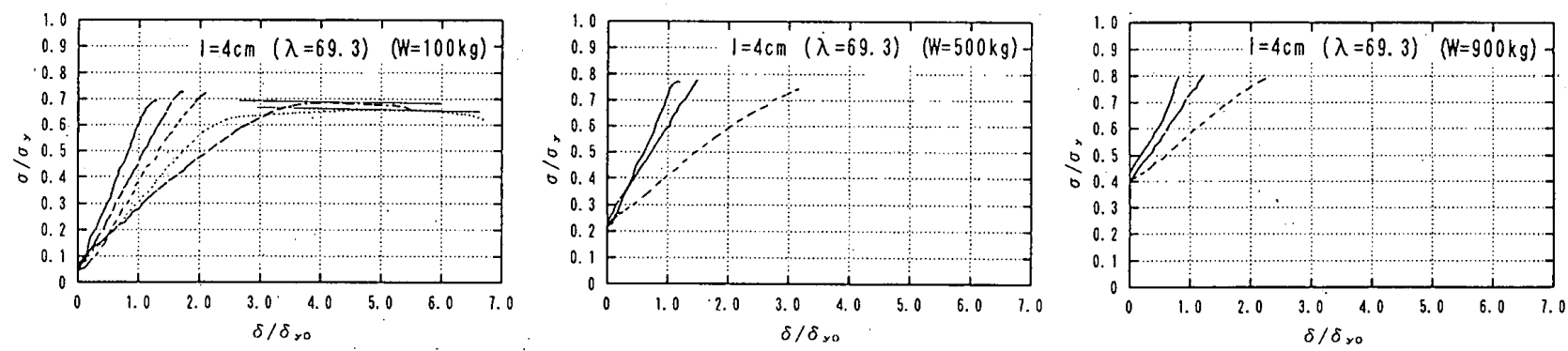

$l=4 \mathrm{~cm}(\lambda=69.3)$

图4 实跧䊅果 


\section{3. 数値解析}

\section{1 解析方法}

数值解析で座屈圧縮応力度 $\sigma_{\mathrm{cr}}$ と座屈時水平変位 $\delta_{\mathrm{cr}}$ の関係を求めて実験結果と比較する。2.5節で、転倒 モーメント下でのラーメンの座屈は圧縮側の柱の軸力 (固定荷重による軸力と転倒モーメントによる付加軸 力の和）と水平変位のみで決まることがわかった。こ のことから、数值解析はラーメン全体についてではな く压縮側の柱だけについて行えば十分であるといえる。 したがって、ここでは圧縮側の柱だけに着目した数 值解析を行う。この数值解析では、図5中に示寸逆対 称の応力条件下において釣り合い条件を満足する固定 端反力が存在し得ないような状態を柱の座屈状態と定 義し、柱が座屈状態になるような圧縮軸力と柱頭変位 をそれぞれの値を徐々に変化させながら探索する。す なわち、実験結果に則して転倒モーメントと水平変形 下における安定状態を水平変位を増加させつつ求め、 その限界である軸方向下に不安定となる状態を見出す。

数值解析は次の手順で行った (図5)。柱を材軸方向 に均等に分割して微小要素に分け、図のように座標軸 をとる。柱には一定軸力 $P$ が作用しているものとす る。

1. 柱頭変位 $\delta$ を決め、固定端での水平反力 $f$ を弾性 として求める。このことから柱脚部分での曲げ モーメント $M_{0}$ は、 $M_{0}=P \delta / 2+f H / 2$ となる。

2. 各微小要素について、下端部分の変形から次の手 順で上端部分の変形を計算していく。

a. 微小要素の変形 $\Delta y i$ を仮定する。

b. 要素下端部の曲げモーメント $M_{i-1}$ を用いて、要 素上端部の曲げモーメント $M_{i}$ は $M_{i}=P\left(\delta-y_{i-1}\right)+$ $f\left(H-x_{i-1}\right)$ と計算できる。

c. 微小要素内で曲率 $\phi$ は一定とし、その值は上下 両端の曲率の平均の值をとるものとする。一定 軸力 $P$ の下でのモーメントー曲率関係により、b の結果から曲率 $\phi$ は、 $\phi=\phi\left(M_{i-1}\right)+\phi\left(M_{i}\right) / 2$ とな る。

d. 下端部での回転角 $\theta_{i-1}$ から、上端部の回転角 $\theta_{i}$ はc.の結果を用いて、 $\theta_{i}=\theta_{i-1}+\phi \Delta x$ となる。

e. 微小要素内で回転角 $\theta$ は一定とし、その值が上 下両端の回転角の平均をとるものとすると、微 小要素の変形は $\left(\theta_{i-1}+\theta_{i}\right) / 2 \cdot \Delta x$ となる。

f. e. で計算した微小要素の変形とa. で仮定した変 形は等しくなっている必要がある。等しくない 場合は $\Delta_{y i}$ を新たに仮定し、等しくなるまでa. 〜e.を繰り返す。

3. 1. により柱脚での曲げモーメント $M_{0}$ が決まり、 また境界条件より柱脚部での回転角 $\theta_{0}$ は $\theta_{0}=0$ と なるので、これらの值を用いて2.の計算を柱脚か ら柱頭に向かって順次行っていく。各微小要素の
変形の総和 $\Sigma \Delta y i$ が柱頭変位の計算值である。

4. 1. で定めた柱頭変位の仮定值 $\delta$ と 3. の計算で得ら れる柱頭変位の計算值は等しくなっている必要が ある。両者が等しくない場合には固定端水平反力 $f$ を新たに仮定して、計算值が仮定値に収束するま で 1.〜3. を繰り返す。

5. 4. で柱頭変位の計算值が仮定值に収束する場合に は、柱頭変位の仮定值 $\delta$ の值を増加させて再び 1 . 〜 4. を繰り返す。4. で柱頭変位の計算值が仮定值 に収束しない場合には、仮定した柱頭変位 $\delta$ に対 応するつりあい状態が存在せず、座屈状態にある ということになる。

3.2 実験結果と解析結果の比較

数值解析で得た $\sigma_{\mathrm{cr}}$ と $\delta_{\mathrm{cr}}$ の関係と実験結果とを比較 して図6に示す。 $\sigma_{\mathrm{cr}} ， \delta_{\mathrm{cr}}$ は図4と同様に無次元化して、 解析結果を実線で示し、実験結果をプロットしている。 図6によると、 $\delta_{\mathrm{cr}} / \delta_{\mathrm{y} 0}$ が1.0より小さい場合に $\sigma_{\mathrm{cr}}$ の 解析值が実験值よりも多少高い值を示す傾向があるが、 全体的に実験值と解析值はよく対応している。

外柱の長さが短い場合、座屈時の変位 $\delta_{\mathrm{cr}}$ が大きい

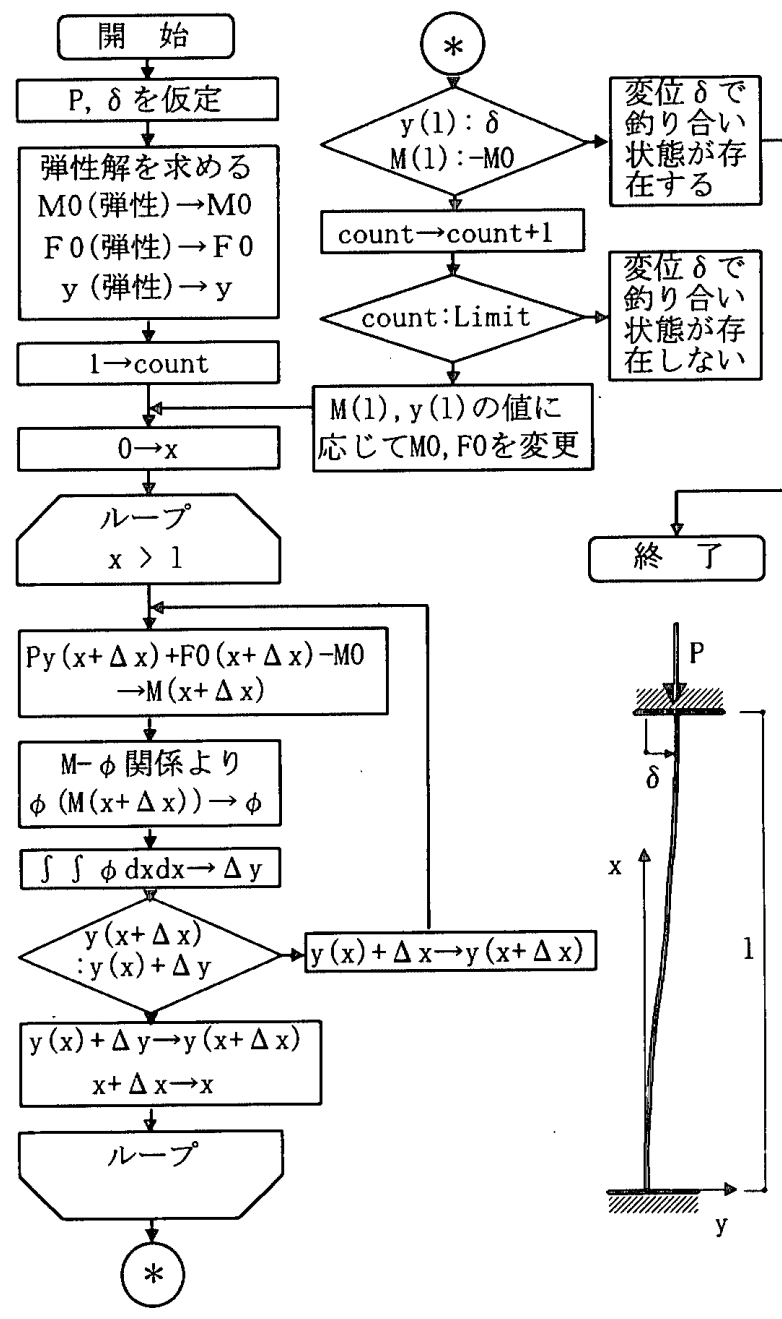

図5 解析プログラムのフローチャート 

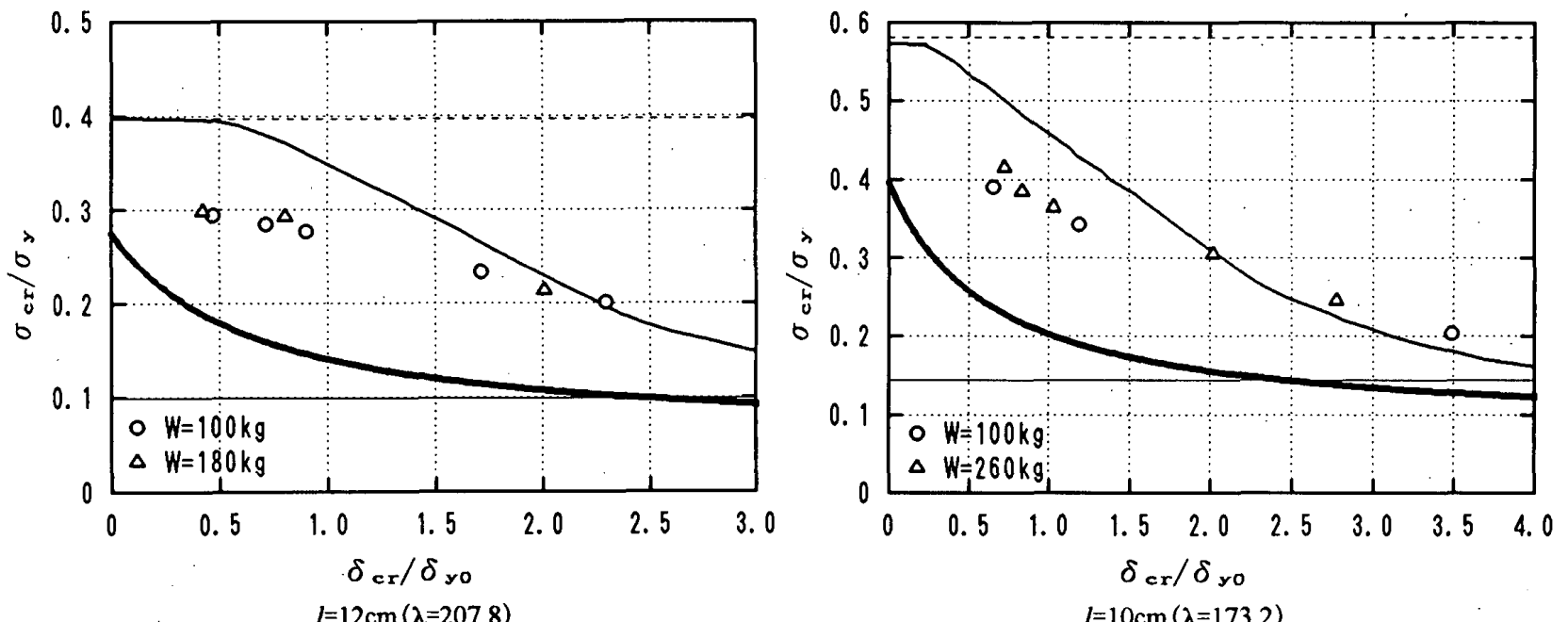

$l=10 \mathrm{~cm}(\lambda=173.2)$

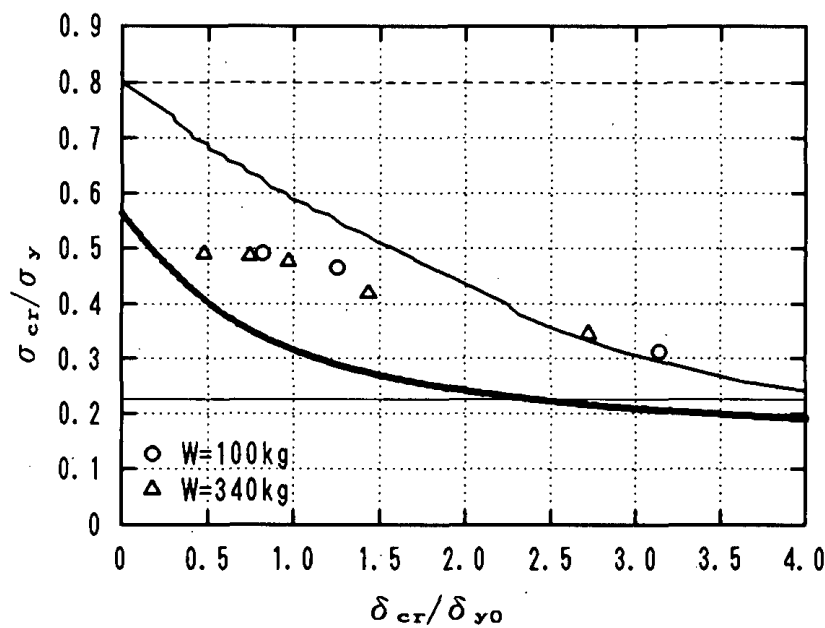

$l=8 \mathrm{~cm}(\lambda=138.6)$

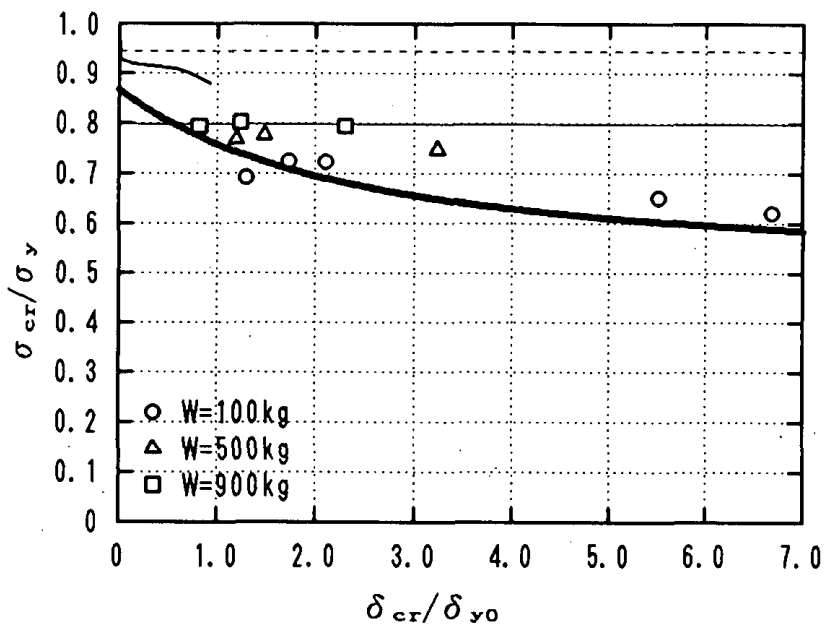

$l=4 \mathrm{~cm}(\lambda=69.3)$

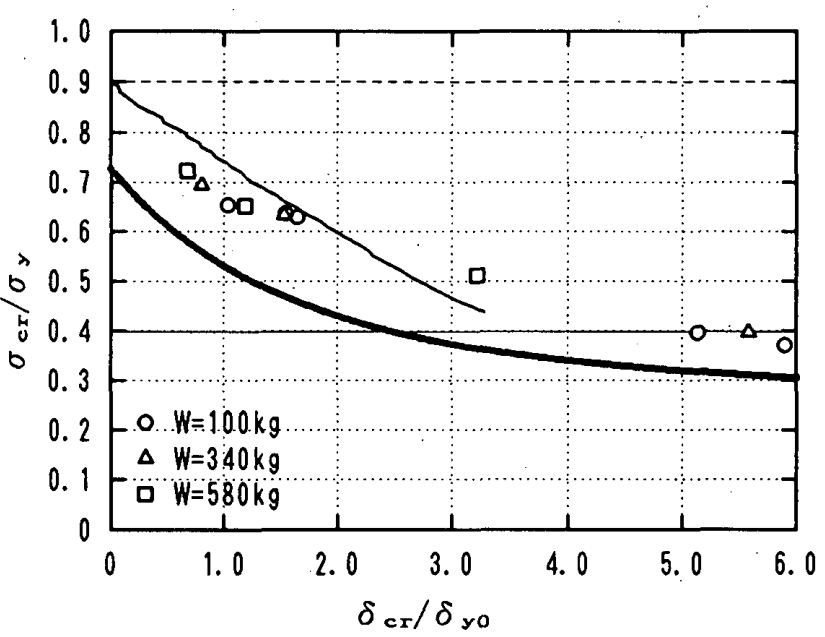

$l=6 \mathrm{~cm}(\lambda=103.9)$

解析結果

設計式（式(5)）

$\sigma$ cr1

図6 解析結果 
ときの座屈時圧縮応力度 $\sigma_{\mathrm{cr}}$ が、1次モードでの值 $\sigma_{\mathrm{cr} 1}$ を下回っていることが図6からわかる。この現象につ いては、柱長さが短くなるほど外柱を精度良く実験装 置にセットするのが難しくなり、外柱にかかる軸力が 偏りやすくなることが大きな理由として挙げられる。 また、3.1節に示したように、解析においては材端が 回転しない逆対称形のモードを仮定しており、解析に よる座屈荷重は1次モードでの座屈荷重を下回ること はない。そのため、座屈時の変位 $\delta_{\mathrm{cr}}$ が大きい場合に は3.1節の解析方法では座屈現象を求める上で限界が ある。 $l=6 \mathrm{~cm}, 4 \mathrm{~cm}$ 場合、解析曲線の右端はこの 解析の限界点を示す。

\section{4. 座届長さ係数による評価と設計式の提案}

\section{1 実験結果について}

転倒モーメントによる付加軸力を受ける柱の座屈応 力度 $\sigma_{\mathrm{cr}}$ を座屈長さ係数 $\gamma$ に換算して評価する。座屈 曲線 (座屈応力度 $\sigma_{c r}$ と細長比 $\lambda$ との関係を示す曲線) が $\sigma_{\mathrm{cr}}=f(\lambda)$ で与えられているとする。実験により得 られた座屈応力度を ${ }_{t} \sigma_{\mathrm{cr}}$ とすれば、柱の等価細長比 $\gamma \lambda$ を用いて ${ }_{t} \sigma_{\mathrm{cr}}=f(\gamma \lambda)$ という関係が成立する。した がって、座屈長さ係数 $\gamma$ は

$$
\gamma=\frac{f^{-1}\left({ }_{t} \sigma_{\mathrm{cr}}\right)}{\lambda}
$$

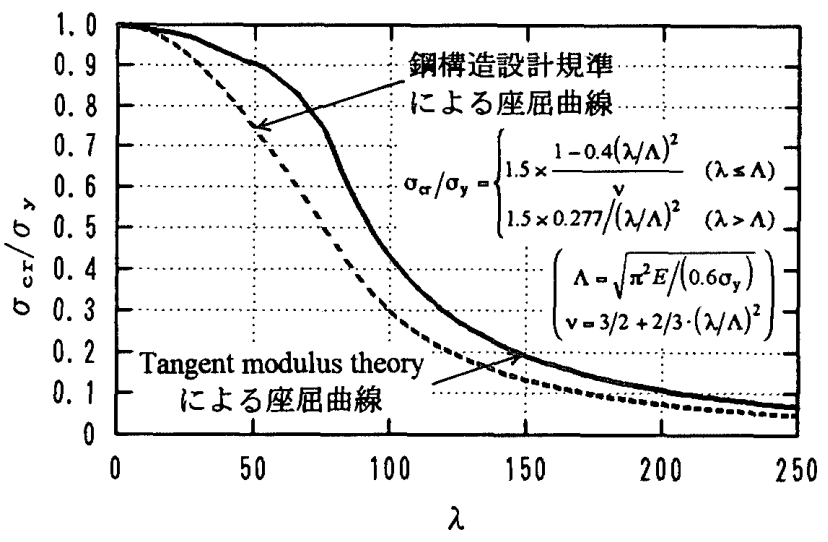

图7 座届曲線

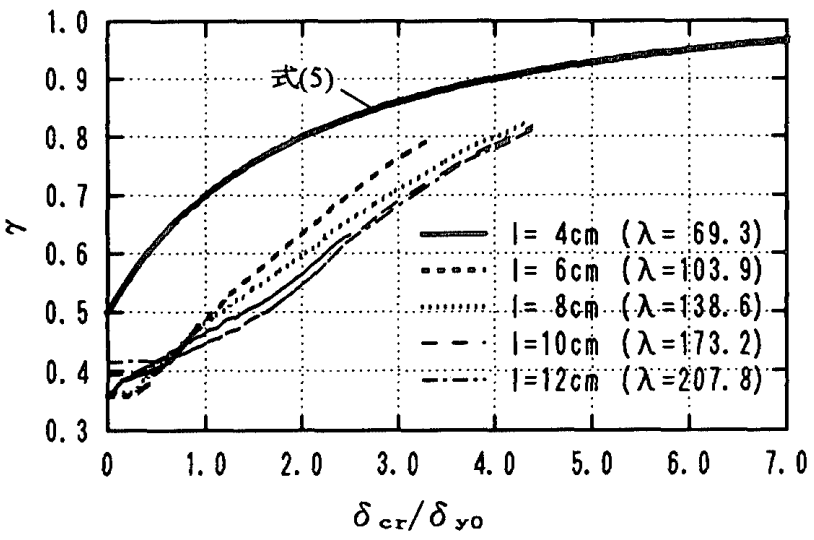

图9 座届唇さ係数(解析結果)
と定義される。式(2)の関係は、座屈長さ係数 $\gamma$ につい て書き換えれば

$$
0.5<\gamma<1
$$

ということになる。

ここで、座屈長さ係数 $\gamma$ は、日本建築学会「鋼構造 設計規準」に示される短期許容応力度に対応する座屈 曲線に関して求める。図7に座屈曲線を示す。図7によ れば、鋼構造設計規準による座屈曲線は、外柱の素材 試験による応力度-歪度関係に基づく Tangent modulus theory による座屈曲線を下回っている。そのため、実 験結果および解析結果を鋼構造設計規淮による座屈曲 線を用いて座屈長さ俰数 $\gamma$ に換算すると、 $\gamma$ の值が 0.5を下回る場合があり、式(4)のようにはならない。

実験結果と 3 章で示した解析結果について、座屈時 の水平変位の無次元化量 $\delta_{\mathrm{cr}} / \delta_{\mathrm{y} 0}$ と座屈長さ係数 $\gamma$ との 関係を図8，9に示す。図8，9によると、外柱の細長比 $\lambda$ によらず、 $\delta_{\mathrm{cr}} / \delta_{\mathrm{y} 0}$ が大きくなるにつれて $\gamma$ もきく なる傾向があることがわかる。

また、図8，9の $\gamma-\delta_{\mathrm{cr}} / \delta_{\mathrm{y} 0}$ 関係は次の式で表される 曲線でほぼ包絡させることができる。

$$
\gamma=1.1-\frac{1.2}{2+\delta_{\mathrm{cr}} / \delta_{\mathrm{y} 0}}
$$

式(5)から導かれる $\sigma_{\mathrm{cr}}-\delta_{\mathrm{cr}} / \delta_{\mathrm{y} 0}$ 関係を図6中に太実線で 示す。図6から、式(5)による $\sigma_{\mathrm{cr}}-\delta_{\mathrm{cr}} / \delta_{\mathrm{y} 0}$ 関係と実験結

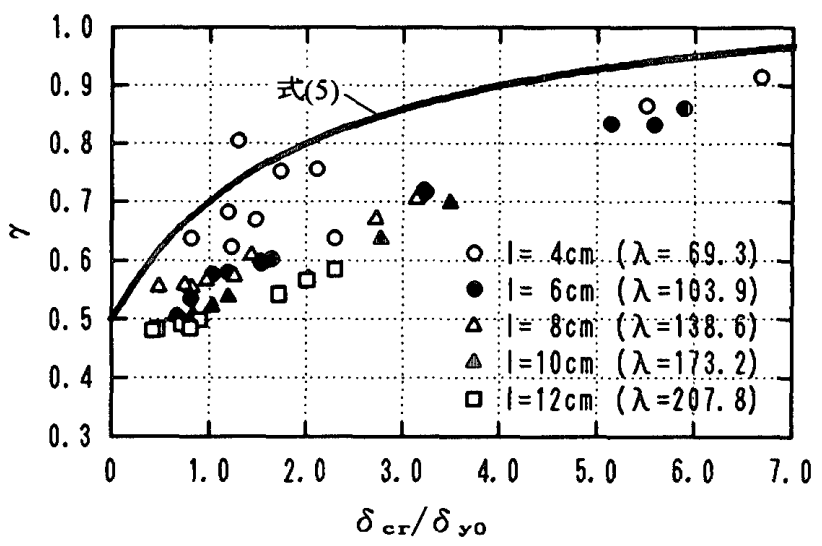

图8 座屈辰さ係数(实験結果)

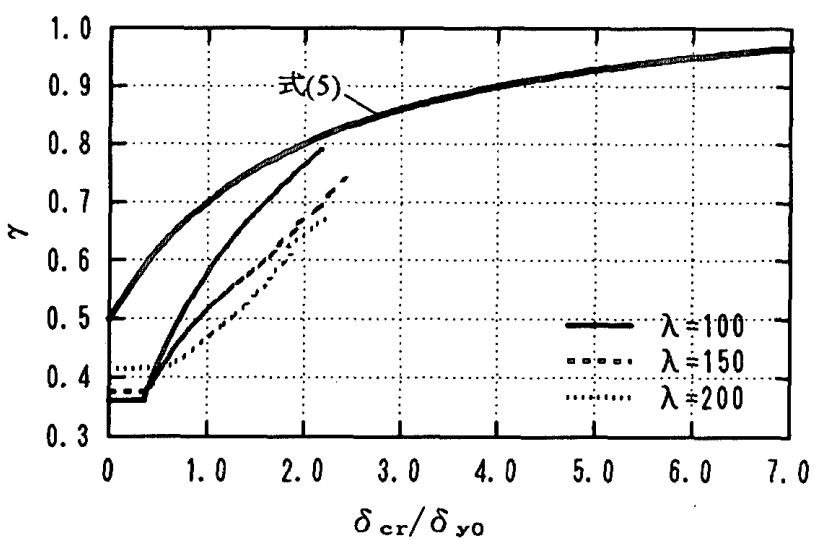

图10 角形鋼管柱の座届長さ係数(解析結果) 
果はよい対応を示していることがわかる。

4.2 実用断面の柱について

本実験では矩形断面の柱を用いたが、実際の構造物 の柱はH形鋼、角形鋼管、円形鋼管などを用いている。 そのため、本実験で得た知見をそのまま実際の構造物 に適用することはできない。しかし、3章で示したよ うに本実験の結果は数值解析で予測することができる ことがわかった。したがって、同じように数值解析を 行えば、実際の構造物の柱に対しても転倒モーメント 下における座屈荷重の予測が可能なはずである。

そこで、柱の断面を角形として3章と同様の解析を 行い、様々な細長比 $\lambda$ について $\gamma-\delta_{\mathrm{cr}} / \delta_{\mathrm{y} 0}$ 関倸を調べた 結果を図10に示す。幅厚比 $D / t$ は20とした。図10によ ると、角形断面の場合の $\gamma$ の値は矩形断面である実験 の場合に比べて多少大きい值をとるが、全体の傾向は 同じである。

ここでは一つの例として角形断面の柱についての解 析結果を示したが、H形断面でも円形断面でもモーメ ントー曲率関係は角形断面のものと大きな差はないか ら、どの断面形状について数值解析を行ってもほぼ同 様の結果を得られる。したがって、図10は、実用断面 の柱の $\gamma-\delta_{\mathrm{cr}} / \delta_{\mathrm{y} 0}$ 関係を代表しているといえる。

図10上に式(5)の曲線を描くと、式(5)の曲線は解析 結果を包絡していることがわかる。つまり、式(5)は実 用断面の柱の $\gamma-\delta_{\mathrm{cr}} / \delta_{\mathrm{y} 0}$ 関係をも包絡している。そこで 筆者らは、式(5)を転倒モーメント下における柱の座屈 に対する設計式として提案する。

\section{3 柱の材端回転角の扱いについて}

本論文で評価した柱の座屈耐力は、柱の材端の回転 が無視できる場合のものである。しかし、実際の構造 物では、梁が変形することによって柱の両端に回転角 が生じる。このような場合には、本論文で示した結果 をそのまま用いることはできない。

柱の材端の回転角が無視できない場合には、柱に作 用する軸力の材軸方向の成分を考えれば、本論文で示 した結果を用いることができる(図11)。層高をh，層 間変形角を $\phi$, 上下の梁の端部の回転角を $\theta_{b}$ であると すると、座屈耐力を評価するための有効軸力 $N_{e}$ と有 効層間変位 $\boldsymbol{\delta}_{e}$ は次のように表される。

$$
\begin{aligned}
& N_{e}=N \cos \theta_{b} \\
& \delta_{e}=h\left(\phi-\theta_{b}\right)
\end{aligned}
$$

式(6),(7)を用いることにより、柱は梁が剛な場合と

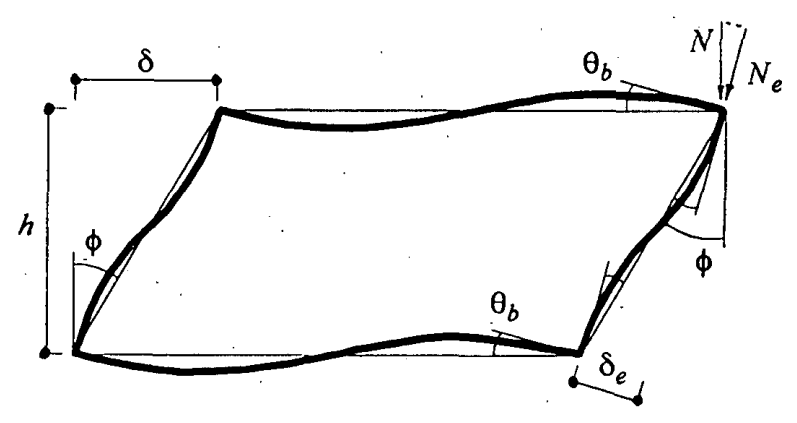

図11 柱の材端の回転角の扱い

同様な境界条件に置かれることになる。柱の座屈は柱 の塑性化の進展による剛性低下に起因寸るものであり、 このような置換は妥当なものであると考えられる。

\section{5. 結論}

簡易な模型を用いて、転倒モーメントを受ける骨組 の柱の座屈現象を実現させることができた。その結果、 転倒モーメントによる付加軸力を受ける柱の座屈耐力 が1次モードの座屈耐力より大きくなることを確認し た。この実駼結果は3章で述べた数值解析により予測 できる。実際の構造物に用いられる柱についても同様 の数值解析を行い、座屈時における水平变位 $\delta_{\mathrm{cr}}$ と座 屈長さ係数 $\gamma$ との関係式(5)を導くことができる。この 式(5)を転倒モーメント下における柱の座屈に対する設 計式として提案する。

\section{謝辞}

本研究の実験に際しては、当時卒論生であった寺田 隆一氏(現 日建設計)及び鈴井康正氏(現 大林組)の両 氏の協力を得た。ここに記して感謝の意を表する。

\section{参考文献}

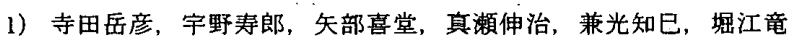
巳，大竹章夫：地譬水平力を受ける銅構造骨組の座屈実臨 (その1. 実験概要およひ結果)，日本建築学会大会学術譜演梗概集， 1990 .

2）三山㓮史，秋山宏：建物のエネルギー吸収層に用いる柱の変形 能力に関する研究, 日本建築学会權造系論文報告集, 第 450 号, 1993.

3）原田幸博，秋山宏：転倒モーメント下における多首骨組の外柱 の座屈耐力, 日本建築学会大会学術詇演梗概集, 1991.

4）笹川和郎：構造物の弾塑性安定応力, 理工学社, 1988.

5）鈴井康正，原田幸博，桑村仁，秋山宏：柔䣓混合エネルギ集中 型骨組の耐震性に関する研究(その1．転倒モーメント下における 柔柱の座屈酎力), 日本建築学会大会学術嫾演梗概集, 1992.

(1993 年 11 月 9 日原稿受理, 1994 年 6 月 30 日採用決定) 